\title{
AS ROSAS QUE O VENTO LEVA: UMA HISTÓRIA PARA NINAR GENTE GRANDE
}

\author{
https://orcid.org/0000-0001-9759-6100 Pâmella Santos dos Passos A \\ ${ }^{\text {A }}$ Instituto Federal do Rio de Janeiro (IFRJ), Rio de Janeiro, RJ, Brasil \\ Recebido em: 4 mar. 2021 | Aceito em: 20 ag. 2021 \\ Correspondência: Pâmella santos dos Passos (pamella.passos@ifrj.edu.br)
}

Quem diria que um par de sapatos tem tantas histórias, memórias, lutas? Nininha, personagem principal do livro As rosas que o vento leva, apaixona suas leitoras e leitores, que assim como ela, desejam passar tardes e mais tardes conversando e escutando os causos de tia Rosa.

O enredo da obra se desenvolve a partir das personagens Nininha e tia Rosa, em especial após o empréstimo de um valioso par de sapatos. Em posse da família há gerações, os sapatos foram feitos pelo avô de Rosa, homem que viveu num tempo de nosso país no qual proteger os pés era um privilégio. Como a própria Nininha explica:

Por isso que o sapato da mãe da tia Rosa era tão especial. Era o sapato de uma família negra que lutou para estar presente na festa da liberdade. Foi um sapato costurado por mãos negras. Era o sapato da vitória. Um troféu. (LIA,2020:23)

Os sapatos da Festa da Liberdade! Mas que festa foi essa? Ocorrida em 16 de maio de 1888, foi organizada pela Caixa Emancipadora José do Patrocínio, com grande participação do avô de tia Rosa. O evento, de origem negra, foi anunciado em jornais, recebeu ilustres abolicionistas e é uma outra data a ser pensada no contexto de 1888. E assim, também através de datas e comemorações podemos diversificar e ir além da assinatura da Lei Áurea por uma representante da Família Real.

Rica em fatos, fontes e problematizações históricas a obra é uma publicação da editora negra Kitabu e foi lançada no turbulento ano de 2020, quando a pandemia do covid 19 nos impôs o isolamento social e episódios como os assassinatos de George Floyd e do menino Miguel, em Recife, escancararam a urgência da luta antirracista.

Com ilustrações de Priscila Paula o livro fala também através de suas imagens, que como os ventos de Iansã sabem ser brisa ou furação. Escrito por Xandra Lia, pseudônimo de Alexandra Lima da Silva, professora do Programa de Pós-Graduação em Educação na Universidade do Estado do Rio de Janeiro (PROPED/UERJ) e que também é pesquisadora Jovem Cientista do Nosso Estado, a obra é uma comprovação de que qualidade acadêmica e popularização não são opostos, tendo recebido financiamento da FAPERJ para sua produção. 
Assim como tia Rosa, Alexandra Lima ou Xandra Lia tem diversas histórias para contar, desde a escrita em seu blog sobre educaçãoi, até artigos e livros, acadêmicos ou não. A autora de As rosas que o vento leva diz ter se inspirado em escritoras negras como bell hooks e Maya Angelou, para assim criar Xandra Lia, a partir de elementos de seu próprio nome. Em suas palavras, este é um momento de transição e o plano é ser Xandra Lia para o público infantojuvenil e Alexandra Lima da Silva para os textos acadêmicos. Nos diferentes nomes, a constatação: somos muitas e diversas nas lutas por sobrevivência.

Historiadora de formação, a jovem professora e pesquisadora negra fez doutorado sanduíche na Universidad de Alcalá e foi professora visitante na University of Illinois. Tal trajetória a aproximou ainda mais das produções de autoras negras e, seguindo os passos de algumas delas, decidiu escrever para crianças e jovens, indo além da academia tradicional.

As rosas que o vento leva é de uma riqueza historiográfica imensa. Seria possível elaborar um curso de História do Brasil a partir das memórias familiares de tia Rosa e Nininha. A Narrativa se inicia com um cotidiano que era comum nas classes populares brasileiras: ir à benzedeira para curar algum mal. E assim, buscando cura para sua caxumba é que Nininha conhece pessoalmente tia Rosa.

Um rico diálogo entre as personagens do livro: tia Rosa e Nininha, nos faz refletir sobre os dias atuais em nosso país. Tia Rosa, em sua sabedoria ancestral, diz a Nininha que a escola é uma conquista do povo e que ela nunca deve abandoná-la.

A luta pela educação pública e de qualidade para o povo negro ainda é uma árdua batalha no Brasil. Não somente para acessar à escola, mas para transformá-la numa escola realmente para todas e todos, pois como também destaca tia Rosa "aposto que seus livros de História não contam a história de nosso povo como eu vou te contar" (LIA,2020:17).

Apesar dos esforços de várias historiadoras e historiadores ainda temos um longo caminho para afirmar e consolidar uma historiografia negra nos livros didáticos de história. Nesse sentido, os elementos históricos trazidos por Xandra Lia em seu trabalho são enriquecedores.

O livro apresenta uma África com regiões islamizadas e falante de Iorubá, como o reino de Oyó. Fatores que trazidos de forma leve podem ser aprofundados em aulas, rodas de leituras ou mesmo conversas informais. Fios para apresentar a complexidade de um continente tão rico como o africano. As crianças de Oyó brincavam à beira do rio Obá e faziam bonecas de barro que secavam ao sol. Nas páginas do livro é possível sentir a brisa, os cheiros e as alegrias dessa vida em comunidade. 
É através da História de Ódòdó e sua filha Ayo que a autora nos apresenta a dureza da diáspora africana. Uma mulher e uma menina vindas de uma vila que foi vendo seus habitantes desaparecerem misteriosamente e que vivia um clima de muitas guerras em seu entorno.

Foi buscando segurança e paz que a família de Ódòdó decidiu abandonar a vila em que moravam. No caminho uma tempestade fez o grupo se perder e ainda confusa ela acorda no porão de um navio negreiro. Gritos, cheiro forte, sua filha Ayo encolhida com frio e fome, ela presa. A cena do sequestro europeu dos povos africanos.

Uma forte febre faz com que Ayo não resista. Nesse momento a belíssima ilustração de Priscila Paula e a descrição de Xandra Lia fazem as leitoras e leitores sentir a dor desta mãe, que tem o corpo de sua filha jogado ao mar.

A dor era tanta que Ódòdó sentiu, que naquele dia ela também morria. Ela sangrou por duas semanas. Havia muito gemido, e ela não entendia quase nada do que era dito pelas pessoas que compartilhavam com ela a dor daquela travessia infame. (LIA, 2020:35).

Ainda no porão escuro, fétido e cheio de dor do navio que a arrancara de sua terra, Ódòdó conhece um belo rapaz que fala o mesmo idioma que ela e assim pode lhe oferecer palavras de força e conforto. Ao aportarem no Brasil recebem, contra sua vontade, novos nomes. Ela passa a se chamar Luíza e ele Antônio.

O ano era de 1830 no porto da Bahia onde foram vendidos e separados. Luíza e Antônio passaram a se encontrar as escondidas, falavam em iorubá e nesses encontros Antônio ensinou sua amada a escrever em árabe. Após a Revolta dos Malês em 1835 Antônio foi enviado para o Sul do Brasil e Luíza vendida para um viúvo branco do Rio de Janeiro.

E assim, através das memórias e histórias da vida de Luiza no Rio de Janeiro podemos conhecer e problematizar a sociedade carioca escravocrata do século XIX, bem como a imensa e rica resistência do povo negro na luta por sua abolição.

Os episódios da vida de Luíza e sua família são riquíssimos para levantar questões da História de nosso país, da importância da ancestralidade, da força e do papel das mulheres durante a diáspora africana e no processo de libertação negra. Como apontava tia Rosa no início de toda a conversa: infelizmente os livros de História ainda não contam tão bem a história do povo negro e seus ancestrais.

Ao final do livro, nos é apresentada uma linda imagem da árvore genealógica de Ódòdó (Luíza). Num país onde Silvas e Santos são desvalorizados por representarem nomes de origem escravizada conhecer e ilustrar as origens da enorme e guerreira família de Luíza é afirmar uma "história que a história não conta". 
Em "As rosas que o vento leva" o vento é uma metáfora da perda de pessoas queridas, é uma forma poética de lidar com a dor. Num país onde a desigualdade econômico-racial ainda é tão presente e o genocídio da população negra é crescente, a leitura deste livro se torna urgente.

Assim como o samba da Mangueira, escola campeã no carnaval de 2019, o livro As rosas que o vento leva é uma "História para ninar gente grande". Que possamos afirmar e cantar “Brasil, chegou a vez, De ouvir as Marias, Mahins, Marielles, malês".

\section{Referência:}

LIA, Xandra. As rosas que o vento leva. Rio de Janeiro: Kitabu Editora, 2020.

' $\underline{\text { https://pensaraeducacao.com.br }}$ 